\title{
One (Firm) Is Not Enough: A Legal-Economic Analysis of EC-Fasteners
}

\author{
CHAD P. BOWN* \\ DECTI, The World Bank, Washington, DC, USA \\ PETROS C. MAVROIDIS * * \\ EUI, Firenze, Italy
}

\begin{abstract}
The WTO's Appellate Body (AB) dealt with a number of issues for the first time in this Report. Importantly, it discussed the consistency of the European Union (EU) regulation with the multilateral rules on the conditions for deviating from the obligation to calculate individual dumping margins. Although China formally won the argument, the $\mathrm{AB}$ may have opened the door to treat China as a nonmarket economy (NME) even beyond 2016 when China's NME status was thought to expire under the terms of China's 2001 WTO Accession Protocol. The $\mathrm{AB}$ further dealt with numerous other issues ranging from statistical sampling to the treatment of confidential information. In handling its investigation, the EU authorities made a number of questionable decisions regarding the collection of information, and this aspect of the process was central to China's legal challenges.
\end{abstract}

\section{The legal facts}

China complained against an imposition of antidumping (AD) duties by the European Union $(\mathrm{EU})^{1}$ concerning various classes of fasteners. China advanced a series of claims before the Panel and prevailed in the most significant ones, chief among them the claim that China's treatment as a nonmarket economy (NME) entailed specific consequences, and did not amount to a licence to impose AD duties on presumptions rather than on hard facts.

The Panel had found that the EU had violated its obligations under Articles 6.10 and 9.5 AD by imposing countrywide $\mathrm{AD}$ duties against Chinese exporters solely

\footnotetext{
* Email: cbown@worldbank.org.

**Email: Petros.mavroidis@unine.ch.

Thanks to Jasper-Martijn Wauters and Mark Koulen for excellent comments during the conference organized at EUI on 4 June 2012, and to Aksel Erbahar for providing outstanding research assistance. Any opinions expressed in this paper are the authors' and should not be attributed to the World Bank. All remaining errors are our own.

1 Throughout this paper, we use the acronym EU to refer to the defendant. In fact, this acronym has already been substituted for the term EC (European Community) in the WTO glossary. The official name of the Report we discuss here is, of course, EC-Fasteners since the Panel had been established before the Treaty of Lisbon, which provoked the change from EC to EU, entered into force.
} 
because China was considered to be an NME; in particular, the Panel found that specific provisions of the EU legislation ${ }^{2}$ (the Market Economy Test, MET, and the Individual Treatment, IT) were in violation of the above-mentioned provisions. Importantly, the Panel found that the EU measure was at odds with the AD Agreement both 'as such' (that is, irrespective of its application in particular cases) and 'as applied' in the present dispute.

Here is how the EU system works: the EU will subject all imports from NMEs to countrywide dumping margins, except for the following instances (quoted from paras. 7.49-7.50 of the Panel Report):

7.49. Article $9(5)$ provides for an exception to the specification of a countrywide duty rate. It provides:

'Where Article 2(7)(a) applies, an individual duty shall, however, be specified for the exporters which can demonstrate, on the basis of properly substantiated claims that:

'(a) in the case of wholly or partly foreign owned firms or joint ventures, exporters are free to repatriate capital and profits;

(b) export prices and quantities, and conditions and terms of sale are freely determined;

(c) the majority of the shares belong to private persons; state officials appearing on the board of directors or holding key management positions shall either be in minority or it must be demonstrated that the company is nonetheless sufficiently independent from State interference;

(d) exchange rate conversions are carried out at the market rate; and

(e) State interference is not such as to permit circumvention of measures if individual exporters are given different rates of duty.'

These criteria are generally referred to as the 'individual treatment ('IT')' test. If a producer demonstrates that it meets these conditions and is thus entitled to IT, the EU authorities will specify an individual duty rate for that producer. Exporters who do not satisfy the IT test will be subject to the country-wide duty rate.

7.50. In sum, when an exporter from a WTO Member that the European Union treats as a NME is subject to an anti-dumping investigation conducted by the European Union, the following possibilities with respect to the determination of normal value and the imposition of duty apply:

(a) If the exporter satisfies the MET, then its normal value will be determined on the same basis as for producers in market economies. A dumping margin for that producer will be calculated by comparing that normal value to the export prices of that producer, and an individual duty rate will be applied to that producer.

(b) If the exporter fails the MET ('NME exporter'), then its normal value will be determined on the basis of an alternative method (typically based on 
prices in an analogue third country). Whether the export price used in calculating the dumping margin will be based on the exporter's own export sales will depend on whether the exporter requests and is granted IT.

(i) If the NME exporter makes such a request and demonstrates that it meets the criteria in Article 9(5) of the Basic AD Regulation, the NME exporter will have an individual duty rate applied to it, calculated on the basis of a comparison of the alternative-method normal value with its own export prices.

Otherwise, the non-IT NME exporter will be subject to a country-wide duty rate. The determination of the export price used to calculate that country-wide duty rate will depend on the level of cooperation on the part of the non-IT exporters altogether. If the level of cooperation is high, i.e. if the cooperating non-IT exporters account for close to $100 \%$ of all exports, the export price will be based on a weighted average of the actual price of all export transactions effected by these exporters. If, however, the level of cooperation is low, i.e. if the non-IT exporters account for significantly less than 100 percent of all exports, the Commission will resort to facts available to complete the missing information. The selection of the facts available will depend on the gravity of non-cooperation and may include statistical import data.

The Panel found that the EU measure was inconsistent with the EU obligations under Article I GATT, since the EU was treating imports from NMEs worse than imports of like products from market economies.

The Panel upheld China's claims to the effect that the EU measure constituted a violation of Article 6.2 $\mathrm{AD}$ and 6.4 $\mathrm{AD}$ since the EU based its decision to impose $\mathrm{AD}$ duties on facts other than those that it had requested the Chinese exporters to provide. It finally found that the EU had violated its obligations regarding treatment of confidential information since it accepted that the entities supplying similar information did not have to also provide a nonconfidential summary. The Panel rejected the Chinese claims regarding the consistency of the EU practices with Article 2.4 AD, which requests WTO Members to perform a fair comparison between normal value (NV) and export price (EP). It decided to exercise judicial economy and not rule on claims regarding the consistency of the EU measure with Articles 9.3 and 9.4 AD, as well as with Article X.3 GATT.

The parties to the dispute challenged all findings mentioned supra, and the Appellate Body $(\mathrm{AB})$ had its hands full yet again in the context of a dispute coming under the purview of the AD Agreement. ${ }^{3}$

3 WTO Members typically raise the highest number of claims per dispute when litigating the consistency of contingent-protection instruments, see Horn et al. (2011), and also www.worldbank.org/ trade/wtodisputes (last visited 15 October 2012). The World Bank's Temporary Trade Barriers Database 
Section 2 provides a brief background of the economic markets involved in this case and a related antidumping investigation and WTO dispute. In Section 3, we briefly discuss the appealed issues and in the immediately following Section 4 we present, in detail, the findings of the $\mathrm{AB}$ on each one of them. Section 5 contains our analytical assessment of some of the key areas of the AB Report in which the issue of statistical sampling arose. Section 6 concludes.

\section{The economic facts and markets involved}

This section briefly describes some of the underlying economic features of the traded products subject to the antidumping measure, WTO dispute, and related policies - all based on publicly available data.

\subsection{The EU import market for steel fasteners}

In November 2007, the European Union initiated an antidumping investigation into imports of certain steel fasteners from China. A fastener is a hardware device that joins two or more objects together. The EU's preliminary investigation was completed in August 2008 without imposition of preliminary measures. The final determination resulted in the imposition of antidumping measures in January of 2009.

Table 1 summarizes some of the key features of the EU steel fasteners import market and policies that affect its imports of those products. The EU's applied MFN tariff on steel fasteners imports was $3.7 \%$, a rate identical to its WTO binding. Domestic petitioners in the European Union's steel fasteners antidumping investigation were represented by the European Industrial Fasteners Institute (EIFI). While the actual number and identity of firms behind the EIFI petition are unknown, in terms of geographic distribution of reported production in the EU's official antidumping announcement, the EU reported verifying the surveyed domestic-producer information of five firms from Italy, one from Poland, and one from Sweden-firms allegedly chosen in part because they represented a large percentage of total community-wide domestic production. ${ }^{4}$

Of the more than 110 Chinese exporting firms that responded to the EU investigation, eight received individual treatment and firm-specific antidumping measures. The result of the investigation led to two of these firms not facing any antidumping measures, whereas the other six firms faced duties ranging from $26.5 \%$ to $79.5 \%$. One of the Chinese firms facing a zero rate, Yantai Agrati Fasteners Co. Ltd, was the Chinese subsidiary of one of the EU's surveyed domestic producers headquartered in Italy (Agrati SpA). The other Chinese firm facing a zero

(Bown, 2012) contains detailed data on most WTO members' use of antidumping, safeguards, and countervailing duties and is available at http://econ.worldbank.org/ttbd/ (last visited 15 October 2012).

4 These firms were Agrati SpA (Italy), Finnveden Bulten (Sweden), Fontana Luigi SpA and LOBO SpA (Italy), Growermetal Srl (Italy), Invitea SpA (Italy), Societa Bulloneria Europea SpA (Italy), and Srubex Fabryca Lancut SA (Poland). 
Table 1. EU and China steel-fasteners import markets associated with antidumping cases

\begin{tabular}{|c|c|c|}
\hline & European Union & China \\
\hline $\begin{array}{l}\text { Tariff binding levels for } \\
\text { named products }\end{array}$ & $3.7 \%$ & $8.0 \%-10.0 \%$ \\
\hline $\begin{array}{l}\text { Applied MFN tariffs } \\
\text { for named products }\end{array}$ & $3.7 \%$ & $8.0 \%-10.0 \%$ \\
\hline $\begin{array}{l}\text { Total imports of named } \\
\text { products, } 2008\end{array}$ & $\$ 2.1$ billion & $\$ 1.4$ billion \\
\hline Domestic firms & $\begin{array}{l}\text { - European Industrial Fasteners Institute } \\
\text { (EIFI) }\end{array}$ & $\begin{array}{l}\text { - China's Industrial } \\
\text { Association of } \\
\text { Mechanical General } \\
\text { Parts }\end{array}$ \\
\hline $\begin{array}{l}\text { Foreign firms } \\
\text { (antidumping duty) }\end{array}$ & $\begin{array}{l}\text { - Biao Wu Tensile Fasteners Co. Ltd } \\
(69.9 \%) \\
\text { - Celo Suzhou Precision Fasteners Co. Ltd } \\
(0.0 \%) \\
\text { - Changshu City Standard Parts Factory } \\
\text { and Changshu British Shanghai } \\
\text { International Fastener Co. Ltd }(63.1 \%) \\
\text { - Golden Horse (Dong Guan) Metal } \\
\text { Manufactory Co. Ltd ( } 26.5 \%) \\
\text { - Kunshan Chenghe Standard } \\
\text { Components Co. Ltd (79.5\%) } \\
\text { - Ningbo Jinding Fastener Co. Ltd } \\
\text { (64.4\%) } \\
\text { - Ningbo Yonghong Fasteners Co. Ltd } \\
\text { (78.3\%) } \\
\text { - Yantai Agrati Fasteners Co. Ltd (0.0\%) } \\
\text { - Cooperating exporting producers } \\
\text { (77.5\%) } \\
\text { - All other companies (85.0\%) }\end{array}$ & $\begin{array}{l}\text { KAMAX-Werke Rudolf } \\
\text { Kellermann GMBH \& } \\
\text { Co. KG }(6.1 \%) \\
\text { - All other companies } \\
(26.0 \%)\end{array}$ \\
\hline
\end{tabular}

Source: compiled by the authors from Bown (2012), WITS and Eurostat.

rate, Celo Suzhou Precision Fasteners Co. Ltd, was the Chinese subsidiary of Grupo Celo, a Spanish-headquartered company that was not involved in the public report. For more than 100 other Chinese exporters that the EU deemed to have cooperated with the investigation, they faced a common countrywide rate of $77.5 \%$, and the all other (noncooperating) firms faced a rate of $85.0 \%$.

According to trade data that are publicly available at the tariff-line level, the EU steel-fasteners market for the product ultimately subject to its antidumping measures peaked at $\$ 2.1$ billion in extra EU imports in 2008, having doubled from its 2005 level. As Figure 1(a) illustrates, more than half of the growth in EU imports of this product during this period came from China alone. EU steelfasteners imports from China peaked at $\$ 1.1$ billion in 2008 , having risen steadily from $\$ 100$ million less than a decade earlier. China's exports of this product to the 
Figure 1. EU import market for certain steel fasteners, 2002-2010

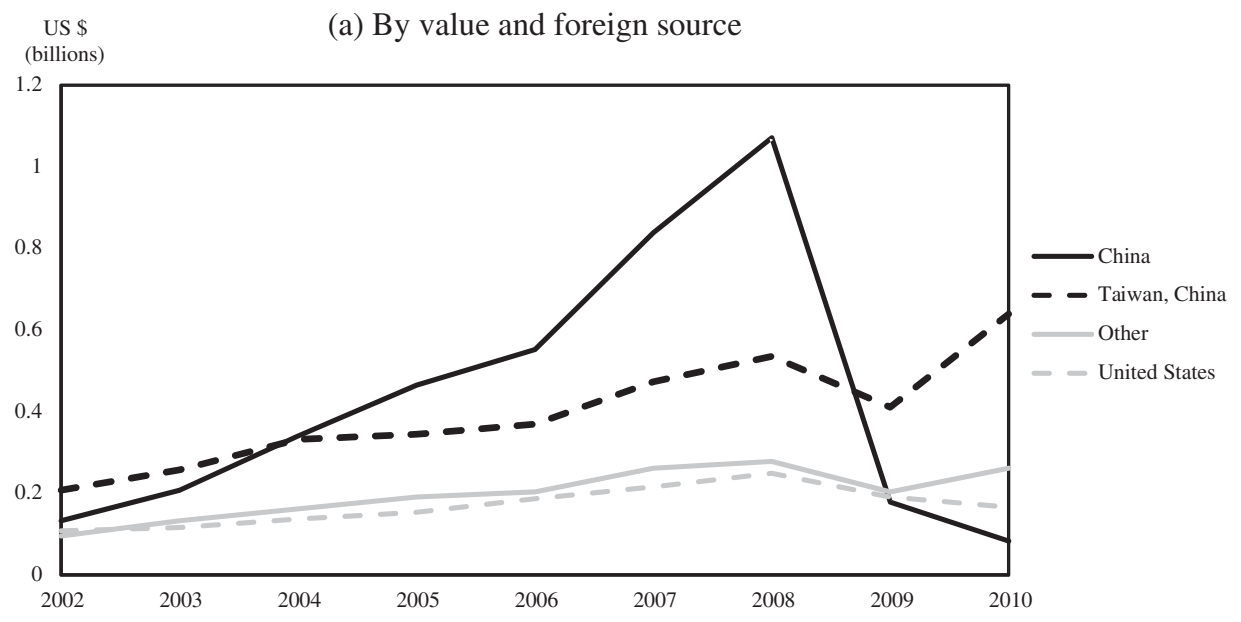

(b) Import market shares by volume (tonnes) and foreign source

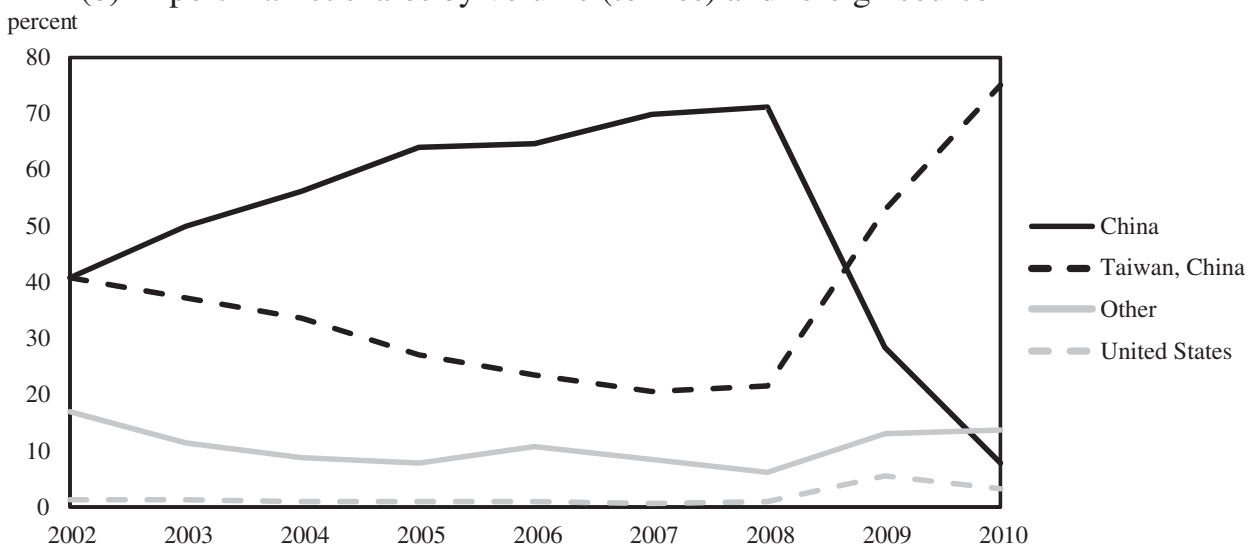

Source: Compiled by the authors with data from Bown (2012) and Eurostat.

EU dropped off considerably after imposition of the antidumping measure, falling by more than $\$ 1$ billion to $\$ 82$ million by 2010 .

Figure 1(b) illustrates China's share of the EU import market for these products had risen to more than $70 \%$ by 2008 , falling off to only $8 \%$ by 2010 after imposition of the measure. Other major foreign suppliers of the EU market for these particular products included Taiwan, China, and the United States - indeed, most of the EU import market share vacated by China due to the imposed antidumping measure was reallocated toward imports from Taiwan, China - from $22 \%$ in 2008 to $75 \%$ in 2010 . Nevertheless, a combination of the antidumping measure on China and weak overall EU import demand associated with the Great 
Recession and the lingering European debt crisis has resulted in the total volume of EU imports of steel fasteners dropping off considerably. While not shown in the figures, the data indicate that by 2010 total EU import volumes were only $40 \%$ of their peak level reached in 2007.5 The value of total EU steel-fasteners imports of $\$ 1.1$ billion in 2010 was also back to its 2005 level, $54 \%$ of its peak level reached in 2008 .

Finally, it is also noteworthy that in October 2010, the EU began an anticircumvention investigation examining allegations that the Chinese exporters subject to the EU antidumping order on steel fasteners were shipping their product through Malaysia. As of 2010, Malaysia exported only $\$ 12$ million in steel fasteners to the EU, $1 \%$ of the extra-EU import market by value $(2 \%$ by volume) - though this had increased from less than $0.5 \%$ just two years earlier. In July 2011, the EU extended the antidumping measures imposed on China to at least 11 firms in Malaysia (European Union, 2010, 2011).

\subsection{China's import market for steel fasteners}

While the EU's antidumping case and China's associated WTO challenge were limited to the facts at issue in the EU antidumping case, any discussion of the political-economic background to the dispute would be incomplete if it did not also inform on the related Chinese antidumping investigation and measures imposed on imports from the EU. This is appropriate given the timing of two cases that covered potentially quite similar products and possibly affecting an overlapping set of firms that compete in both markets.

Less than one month before the final decision in the EU's antidumping investigation, China announced it was initiating an antidumping investigation of its own over certain steel fasteners imports from the EU. The antidumping investigation was initiated in December 2008; China imposed provisional antidumping duties in December 2009. In May of 2010, the WTO received a formal DSU request for consultations from the EU regarding the provisional antidumping duties that China had applied. In June 2010, China applied final measures.

Table 1 also summarizes key features of China's steel-fasteners import market and import policies. China's applied MFN tariff on the steel fasteners under its antidumping investigation was either $8.0 \%$ or $10.0 \%$, depending on the specific product variety named in the investigation. For each named variety, however, China's applied MFN tariff was identical to its WTO binding; thus, like the EU, it also had no scope to raise applied MFN tariffs. The domestic petitioner in China's steel-fasteners antidumping investigation was China's Industrial Association of

5 According to the 8-digit tariff line Eurostat import data, extra-EU total imports of the steel fasteners at issue in the antidumping investigation totalled 904 thousand tonnes in 2007 and fell to 351 thousand tonnes in 2010 . 
Figure 2. China's import market for certain steel fasteners, 2002-2010

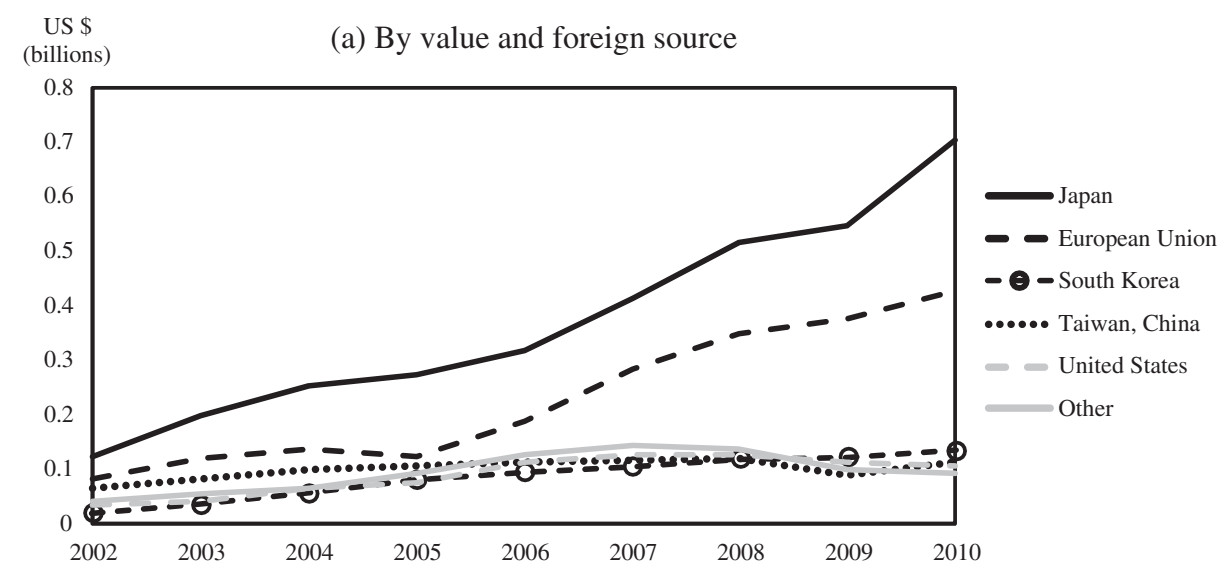

percent (b) Import market shares by volume (tonnes) and foreign source

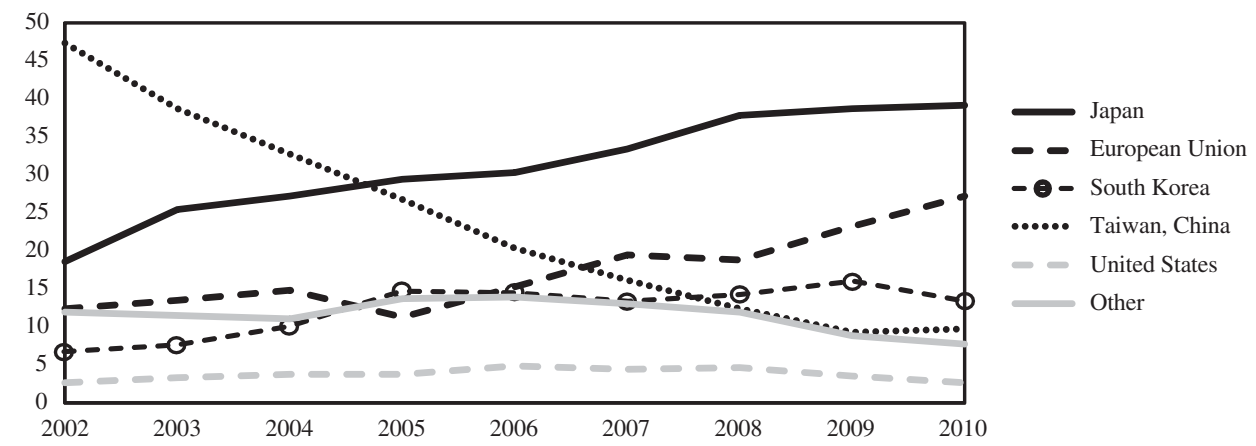

Source: Compiled by the authors with data from Bown (2012) and UN Comtrade made available via WITS.

Mechanical General Parts; the exact set of domestic firms behind the petition is unknown. There was only one European firm named in the antidumping investigation-KAMAX-Werke Rudolf Kellermann GMBH \& Co. KG-and China imposed a $6.1 \%$ antidumping duty on its exports. The European firm KAMAX was headquartered in Belgium and provided steel fasteners primarily for the auto industry. KAMAX had other subsidiaries across the EU, United States, and Japan, in 2010 it established a trading company in China, and subsequent to China's antidumping decision in 2012 it announced it had begun construction of its first production plant in China (KAMAX, 2012a,b). For all other European exporters, China applied an all-other-firm rate of $26 \%$.

Figure 2(a) illustrates that China's import market for the steel-fasteners product ultimately subject to its antidumping measures was $\$ 1.4$ billion in 2008 , also 
having doubled from its 2005 level. ${ }^{6}$ Steel-fasteners imports from the EU had nearly tripled during this period, from $\$ 124$ million to $\$ 349$ million. Figure 2(b) illustrates the EU's share of China's import market for these products had risen to $19 \%$ by 2008 , accelerating to $27 \%$ by 2010 at the time of the imposition of the final antidumping measure, when it was expected to begin to decline. The other major foreign suppliers to China's market for these particular products are Japan; Taiwan, China; South Korea; and the United States. Like the EU, Japan's share of the China import market for these products had also increased considerably during this time period - increasing by nearly 10 percentage points (from $30 \%$ to $39 \%$ ) between 2006 and 2010. In volume terms, Figure 2(b) shows the growth in Japanese and EU share of China's import market during this time period is largely coming at the expense of Taiwan, China, and to a lesser extent from the United States and South Korea.

While not shown in the figures, it is also worth noting that the Great Recession did not result in a substantial, long-run impact on China's total imports of these products, unlike the case for the EU described earlier. China's overall imports of steel fasteners by 2010 were nearly 33\% higher than their 2007 levels by value and nearly $40 \%$ higher by volume.

\subsection{Differentiating between the EU and China certain steel-fasteners markets}

While both the EU and China's antidumping cases referred to certain steel fasteners, to what extent are these similar or even substitutable products? The simple fact that there was substantial two-way trade in steel fasteners across long geographic distance suggests that these products are likely to be somewhat differentiated. ${ }^{7}$

One possibility is that these products are differentiated along the dimension of complexity or product quality (Schott, 2008), what has come to be known in economics as occupying different places on the 'quality ladder' (Khandelwal, 2010). Figure 3 provides a first pass at this question by examining the unit values

\footnotetext{
6 This figure is also derived from publicly available data. However, unlike the EU data which derive from Eurostat, the Chinese import data are not at the tariff-line level but instead the 6-digit HS level from WITS. Nevertheless, according to the available data from China's tariff-line tariff codes, the 8-digit tariffline codes listed in its antidumping investigation cover all of the sub-products within the more aggregated 6digit HS product codes, suggesting in this instance that the 6-digit HS data series is identical to summing up the 8-digit HS data.

7 Next, it turns out that one half of the 8-digit product lines in the relevant HS-06 product categories for the EU were left out of the antidumping investigation. The following HS08 lines were included in the EU's antidumping petition: 73181290, 73181491, 73181499, 73181559, 73181569, 73181581, 73181589, 73181590, 73182100, and 73182200. The HS08 lines within the same HS06 product categories that were left out of the petition were 73181210, 73181410, 73181510, 73181520, 73181530, 73181541, 73181549, 73181551, 73181561, and 73181570. As noted above, this is different from China's antidumping case in which all of the 8-digit tariff lines within the HS06 product categories were part of the antidumping investigation.
} 
Figure 3. Import price comparison for EU vs. China's certain steel-fasteners products in $\mathrm{AD}$ cases

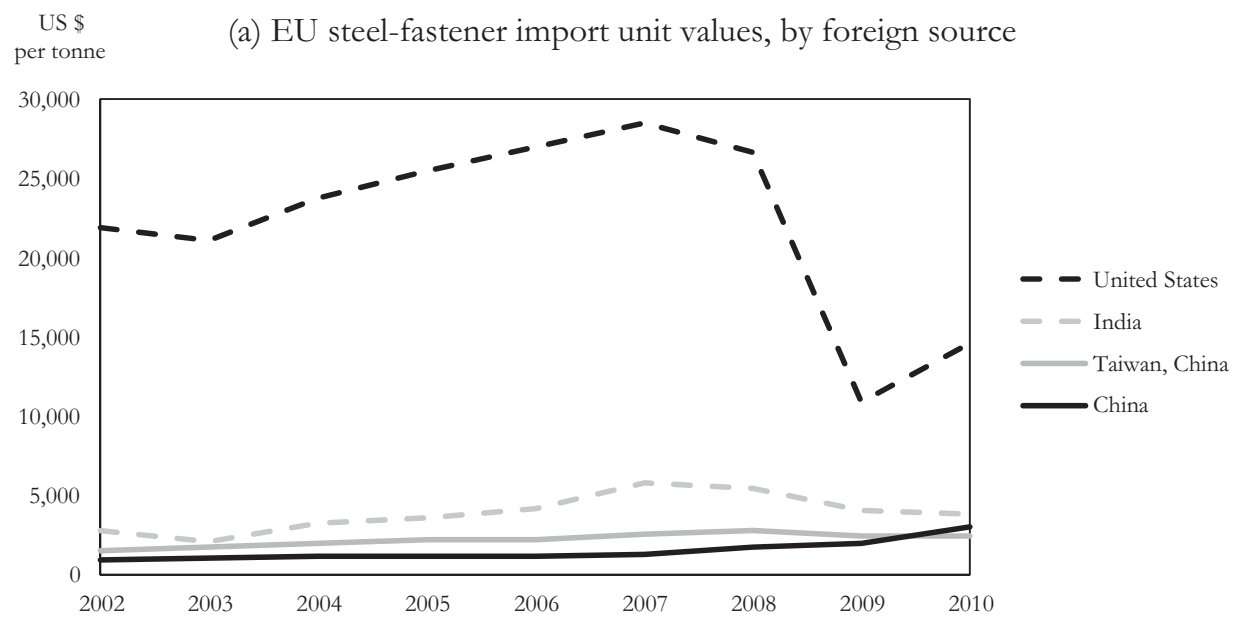

$\begin{array}{cl}\text { US } \$ & \text { (b) China's steel-fastener import unit values, by foreign source }\end{array}$

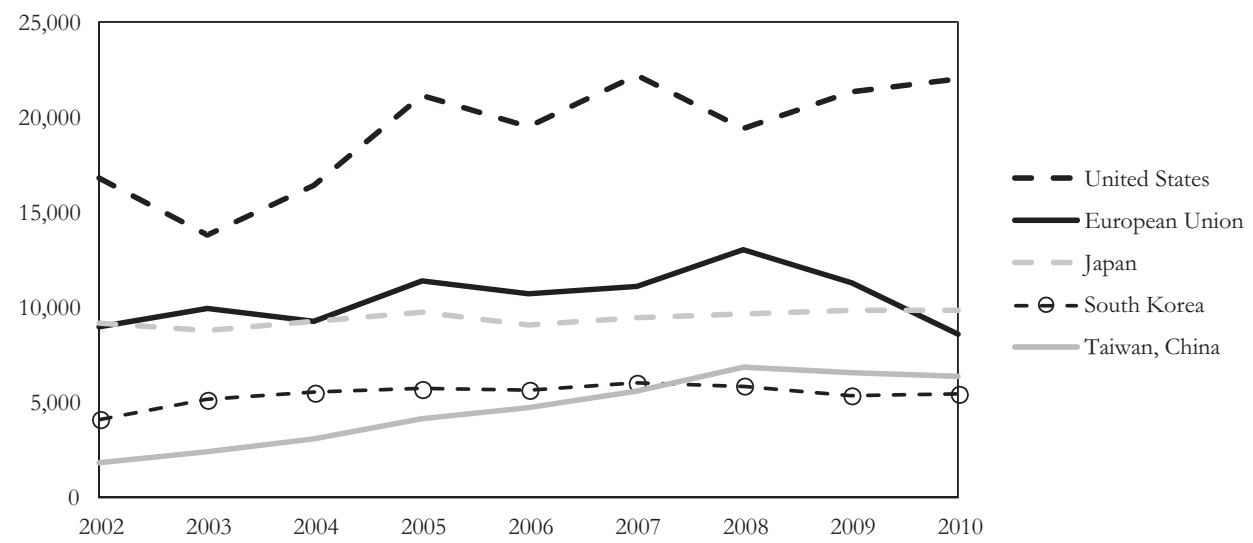

Source: compiled by the authors with data from Bown (2012), Eurostat, and UN Comtrade made available via WITS.

for the certain steel fasteners import products across different foreign-source countries. Figure 3(a) illustrates the EU's unit value for imports across four different foreign sources of the eight-digit HS products named in its antidumping investigation (see again Figure 1) - the United States; China; Taiwan, China; and India. Begin with the EU's imports from the United States. Clearly, there is a substantial distinction between the EU's imports from the United States and the EU's imports from China and Taiwan regarding otherwise identical HS08 product 
lines. Before the onset of the global trade collapse of 2008-2009, unit values on imports from the United States averaged between \$21,000 and \$28,000 per tonne each year. ${ }^{8}$ During this same period, unit values on imports from China and Taiwan, China averaged only $\$ 1,000$ to $\$ 3,000$ per tonne-suggesting a substantially differentiated product compared to imports from the United States. The United States had a very small share of the EU's import market (see again Figure 1(b)); together, these facts suggest that the United States may be supplying European customers with a more highly specialized product, and the Chinese and Taiwanese firms may be supplying a relatively more homogeneous variety likely produced at high scale and low cost. ${ }^{9}$

Next, consider the Chinese import market in Figure 3(b). As a benchmark, begin again with the unit values of China's imports from the United States during this period, which ranged from $\$ 14,000$ to $\$ 22,000$ per tonne per year. The fact that these were not as high as the US import unit values in the EU market suggests some level difference in demand for the certain steel fasteners between the EU and China markets. Next, the unit value on Chinese imports of steel fasteners from the EU averaged $\$ 9,000$ to $\$ 13,000$ per tonne during 2002-2010. While this was not as high as China's average unit value on steel fasteners imports from the United States, it is much higher than the unit value of EU imports of steel fasteners from China in its antidumping case illustrated in Figure 3(a). The difference is more stark after accounting for the overall difference in price levels, e.g., by comparing unit values of imports from the United States across the two markets. Thus, using the US import values as a benchmark, a comparison of the import unit values from the products covered by the reciprocal antidumping cases is consistent with a model of China exporting relatively low-end varieties of steel fasteners to the EU market and the EU exporting relatively high-end varieties of steel fasteners to the Chinese market.

Finally, preliminary indicators point to two potentially quite different economic outcomes resulting from the EU and Chinese antidumping cases. While overall EU imports have dropped, a second result from the European imposition of antidumping on imports of steel fasteners from China is likely to be substantial trade diversion. The preliminary evidence (see again Figure $1(\mathrm{a})$ ) is an increase in EU imports from nontargeted exporters such as Taiwan, China, that were historical suppliers producing a similarly priced variety of steel-fasteners imports. Ultimately,

8 Unit values on imports from the United States dropped dramatically during the Great Recession, even as the quantity of imports from the United States nearly doubled between 2008 and 2009.

9 Figure $3 \mathrm{a}$ also illustrates the unit values on EU imports from India. These unit values - ranging between $\$ 2,000$ and $\$ 6,000$ per tonne-were consistently higher than the unit values on imports from China and Taiwan, China - though they were much lower than the unit values on imports from the United States. Even though imports from India of this product were negligible during this period (less than $\$ 3$ million in 2006), this point is interesting given that India was chosen as the analogue country for China in the normal-value calculation. 
this antidumping case results in a relocation of production from China to Taiwan, China, and not necessarily the relocation of substantial production back to the EU. On the other hand, provided KAMAX follows through with the announced production facility in China, China's antidumping duties on imports from the EU of high-end steel fasteners could result in 'tariff-jumping' foreign direct investment (Blonigen, 2002) - that is, a relocation of production from the EU to China.

\section{The issues before the $A B$}

The $\mathrm{AB}$ faced a number of issues from both parties to the dispute ${ }^{10}$ that could, for all practical purposes, be classified as follows:

(a) China's NME status;

(b) the understanding of the term 'major proportion';

(c) the possibility to sample producers in the injury analysis as well (and not only when defining dumping margins);

(d) the attitude of the EU investigating authority (IA) with respect to the 'parallelism' of the subject matter between the requested information and the basis for the EU decision to impose $\mathrm{AD}$ duties;

(e) the treatment of confidential information by the EU.

Claims under heading (a) were, in principle, of transitional value as far as China is concerned since, by virtue of the explicit wording of Article 15 of China's Protocol of Accession, China cannot be treated as an NME after 2016, that is 15 years after its succession to the WTO. And yet, in our view, they carry particular weight: the $\mathrm{AB}$ response is one of the scarce attempts to shed some light on the NME carveout, an issue that for various reasons had not been comprehensively discussed before this Report was issued; the findings here are of relevance to all WTO Members that are considered NMEs. Moreover, as we will try to demonstrate infra, the findings of the $\mathrm{AB}$ in this respect could be viewed as the basis for treating imports from China differently from those originating in market economies beyond 2016 as well. We will address this discussion below.

\section{The $A B$ findings}

\subsection{Individual treatment (China's nonmarket-economy status)}

We described briefly above the MET and IT tests that appear in Articles 9(5) and 2.7(a)-(c) of the EU Regulation. Recall that successful invocation of MET status confers automatically IT, while a failed attempt is not necessarily prejudicial since interested exporters can still request IT; they can also bypass the MET process and

10 Zang (2011) offers a discussion of the dispute with respect to the claims regarding the NME status of China. 
request simply IT. Two questions form the heart of the dispute between China and the EU in this context: first, under what conditions can an IA deviate from its obligations to calculate individual dumping margins? Second, who should carry the burden of proof to demonstrate that an exporter should be considered as originating in an NME?

With respect to the first question, the $\mathrm{AB}$ entertained the claim by the EU to the effect that the Panel got it wrong when it held that under Article 6.10 AD sampling is the only exception to the obligation to calculate individual dumping margins. ${ }^{11}$ The AB, upholding the Panel's findings in this respect, found that the default obligation for WTO Members is to calculate individual dumping margins, the possibility to impose duties on a countrywide basis being reserved only to the cases referred to in the AD Agreement and not to any other case (para. 320 and para. 329). It rejected a number of scenarios offered by the EU where countrywide duties were in order since, in the AB's view, they were all provided for in the AD Agreement and none of them provided justification for the EU practices to impose countrywide duties when exports originate in NMEs (paras. 321-327). The AB thus established that the EU was in violation of its obligations under Article 6.10 $\mathrm{AD}$ when it imposed countrywide duties on Chinese exporters because they originate in an NME: there is no corresponding exception to the obligation to calculate individual dumping margins in the AD Agreement.

Next was the question regarding the allocation of the burden (of production) of proof to show whether an exporter should be considered as originating in an NME or not. Strictly speaking, a finding here was not necessary for the resolution of the dispute: a finding that individual dumping margins could not be lawfully calculated in this case should signal 'game, set and match' for China. The AB nevertheless, facing an appeal to this effect, addressed this issue as well. Recall that according to the EU system described above, it is for the exporter to request MET status (that might lead to IT). Here we care about MET status only. To understand the discussion regarding the conformity of MET with the AD Agreement, we need to place this legal institution in its natural context, that is the NME context.

The AD Agreement does not refer to NMEs at all; they are addressed in Article VI GATT. The AB has consistently held that both the AD Agreement and Article VI GATT are legally relevant to the regulation of antidumping. It is thus through the

11 Sampling can lawfully take place when a statistically valid sample has been chosen or when it is impractical for the IA to calculate individual dumping margins, say, because of the large number of exporters involved. Although the two methods, normatively at least, should not be regarded as equivalent (in the name of impracticality a statistically invalid sample - that is, a sample of producers that does not reproduce the properties of the whole-might be chosen, and thus the investigation might suffer from sample bias), they are recognized as such in Article 6.10 AD. One of the (many) paradoxes of AD is that while dumping is acknowledged to be private business practice, still orders can be applied on countrywide basis without meaningful investigation as to whether the law of one price holds, see on this score the analysis in Mavroidis and Sapir (2008). 
case-law door that NMEs entered into the WTO picture. ${ }^{12}$ NMEs are defined in the Interpretative Note ad Article VI GATT as:

a country which has a complete or substantially complete monopoly of its trade and where all domestic prices are fixed by the state.

The Note allows WTO Members to deviate from the obligations imposed in Article VI GATT (as further explicated in the AD Agreement) but does not explain what methodology exactly they should be following in similar cases:

It is recognized that, in the case of imports from a country which has a complete or substantially complete monopoly of its trade and where all domestic prices are fixed by the State, special difficulties may exist in determining price comparability for the purposes of paragraph 1, and in such cases importing contracting parties may find it necessary to take into account the possibility that a strict comparison with domestic prices in such a country may not always be appropriate.

Normally, an IA, in the absence of legislative guidance as to what to do in such cases, will either use data from third-country producers, or construct the NV. In EU-Footwear (China), the Panel faced a claim by China that, by choosing Brazil as surrogate country for China, the EU had violated its obligations under the AD Agreement; the Panel discarded it, underlining the wide discretion IAs have when choosing surrogate countries for NMEs (paras. 7.253ff.).

Not surprisingly, the NME status of China was an important issue in the Chinese accession process. The Chinese Accession Protocol starts from the principle that WTO Members have a choice either to use Chinese prices or costs for the industry (that is, to treat China as any other market-economy country), or to use a methodology based on the general rule that it is up to the producers under investigation to:

clearly show that market economy conditions prevail in the industry producing the like product with regard to the manufacture, production and sale of that product. $^{13}$

If this has been the case, the importing WTO Member is obliged to use Chinese prices: in other words, if China is able to establish that it is (either as a whole or with regard to a particular industry) a market economy according to the criteria set forth in the importing WTO Member's national law, China (e.g., the Chinese industry in question) must be treated as a normal market economy/industry. In order to benefit from market-economy status, the criteria conferring it must have existed in the importing WTO Member's law at the time of China's accession in 2001 ; it is not entirely clear what happens if similar criteria were not in place at the 
time of China's accession, and it is an open question whether WTO Members finding themselves in this situation are precluded from treating China as an NME. This will be, if at all, a short-lived situation, since the NME status of China will expire, at the latest, 15 years after accession, that is by 2016 .

In the opposite case, a methodology that is not based on a strict comparison with domestic prices or costs in China may be used. If this methodology is applied, the WTO Antidumping Committee has to be notified about it. China's Accession Protocol does not set forth which methodology is to be used in cases where the importing WTO Member does not use Chinese prices and costs; the final report of the Working Party on China's Accession ${ }^{14}$ provides some clarification though in this respect: the authority shall normally utilize, to the extent possible, and where cooperation existed, the prices or costs in one or more market-economy countries that are significant producers of comparable merchandise, and that are either at the level of economic development comparable to that of China, or are otherwise an appropriate source for the prices or costs to be utilized in light of the nature of the industry under investigation. Those WTO Members that do not have an established practice in this respect should make best efforts to ensure that their methodology for determining price comparability is along similar lines. In addition, it provides that due-process rights of Chinese exporters be respected.

It is clear from the discussion above that the burden of proof to show that a company should not be regarded as originating in an NME lies with the Chinese company requesting this privilege: paragraph 15 of the Protocol of Accession says as much. Nevertheless, the burden is allocated to the Chinese company only with respect to the NV. Nothing in the Protocol of Accession imposes the burden on Chinese companies to disavow NME status with respect to EP. With respect to EP, hence, the allocation of the burden of proof reverts to the original distribution; that is, it is for the IA to demonstrate NME status and proceed in the consequential calculation of dumping margins. Paragraph 15 of the Protocol of Accession, in other words, is a limited exception and covers NV only; the EU presumption thus goes against the letter and the spirit of Articles 6.10 and 9.2 AD, the two provisions dealing with calculation of dumping margins (paras. $363 \mathrm{ff}$. of the AB Report, and especially 364 and 366). Since, in the eyes of the AB, the EU measure ran afoul of the WTO 'as such'; that is, irrespective whether it had been applied to a particular case, it also ran afoul as applied in the instant case (para. 409).

The consequence of this finding led the $\mathrm{AB}$ to two more conclusions: first, since duties had in its view been illegally calculated, the obligation to not discriminate had been violated as well, since other exports to the EU market would not suffer from similar treatment (para. 398); second, since the duties had been illegally 
imposed, the EU had ipso facto violated its obligations under Article XVI GATT and 18.4 AD (para. 398).

\subsection{Major proportion of the industry}

The question before the $\mathrm{AB}$, in this respect, was whether the EU decision to find that $27 \%$ of the EU fasteners producers constituted a major proportion of the domestic industry was consistent with Articles 4.1 and 3.1 AD. The latter requires that the determination of injury be based on 'positive evidence' whereas the former obliges WTO Members to examine injury of the domestic producers as a whole, without nevertheless providing a specific quantitative benchmark, say a fixed percentage of the domestic duty the health of which should be discussed in the context of injury analysis.

It is clear from the discussion in the AB Report (paras. 420ff.) that, in the eyes of the $\mathrm{AB}$, the EU was inspired by Article 5.4 AD when deciding on the percentage of the domestic industry (the $27 \%$ ) that validly represents the whole. In the AB's view, this is wrong, since the two provisions are designed to address different issues: Article 5.4 AD deals with the percentage of the domestic industry that must anyway back a petition to (eventually) impose AD duties and the WTO legislator decided that a $25 \%$ threshold was appropriate in order to avoid flimsy requests; ${ }^{15}$ Articles 3.1 and 4.1 AD, on the other hand, are integral parts of the injury analysis where the WTO legislator aims at securing that AD duties will be (eventually) imposed when the industry as a whole has suffered from dumping practices, and not a small, unrepresentative percentage thereof. Indeed, the AB itself, without going the full nine yards and providing a number, did state that the term 'major proportion' points to a 'relatively high proportion' (para. 419). The AB, however, did not give a number here. Actually, it went as far as to state that a major proportion could be less than $50 \%$ on occasion and as low as $25 \%$ in case of fragmented industries (paras. $415 \mathrm{ff}$. .).

Because the EU had inappropriately linked the percentage of the major industry to that in Article 5.4 AD, the AB found that it had violated its WTO obligations in this respect (Article 4.1 AD). Violation of Article 4.1 AD means ipso facto that Article 3.1 AD has also been violated since the major industry has been inappropriately defined and, consequently, AD duties were ultimately imposed in disregard of the requirement to base findings on positive evidence (para. 430). Note, however, that the EU practice has changed and that the link to the standing requirement is no longer EU practice. Finally, in paragraph 460, the AB condoned the EU practice to provide exporters with a 15-day deadline to make themselves

15 It is far from clear that this threshold decisively helps avoid sample bias since the $25 \%$ could, for example, correspond to the part of the industry that did not modernize, did not invest in new technologies/ equipments etc., and as a result might have contributed itself to its downfall. 
known (in case they do not, the EU can, of course, proceed with the remaining exporters).

\subsection{Do you like sampling too?}

This point deserves an introduction. We are not dealing with a new claim here but merely with an argument ${ }^{16}$ in support of the claim discussed immediately supra to the effect that the EU had violated its obligations under Article 3.1 AD: China argued before the Panel and the $\mathrm{AB}$ that the EU had violated its obligations under this provision also because it had picked an unrepresentative sample of domestic producers (a statistically invalid sample) to conduct its injury analysis; having defined the major proportion to comprise $27 \%$ of the domestic production, the EU picked a number (65\% of this sum, that is 45 producers) and went ahead with its investigation.

We dedicate a separate heading to this point because of the novelty of the issue we are confronted with: the AD Agreement allows for sampling when it comes to defining dumping margins; it is silent on sampling for purposes of establishing injury resulting from dumping. Statutory silence was not perceived as an obstacle by the EU authorities to go ahead and sample producers in order to perform the injury analysis.

The $\mathrm{AB}$ did not find anything wrong with the EU practice in this respect. In its view, the absence of specific language allowing sampling in injury analysis is no reason in and of itself to disallow a similar practice (para. 436); the percentage chosen by the EU does not run afoul of its obligations under the AD Agreement since, in parallel with the sampling scenario when defining dumping margins, the EU does not have to pick a statistically valid sample (it can also pick the sample of producers that can be investigated); finally, the EU has every right, in accordance with the $\mathrm{AB}$ to exclude, from its sample, producers that have not responded within 15 days to its questionnaire, otherwise the whole investigation process risks being unduly long (para. 460).

\subsection{Surprise, surprise (you pay for this, but they give you that)}

The whole investigation was conducted using PCNs (Product Control Numbers). Six elements made up the PCNs identified by the Commission, the type of fasteners, their strength/hardness, coating, the presence of chrome on coating, their diameter, and their length/thickness. The Commission sent questionnaires requesting information on this specification of the 'like product' under investigation to Chinese exporters and to Pooja Forge, an Indian company that was used as a surrogate to define dumping margins by the EU Commission (since Chinese exports

16 A claim, as per constant WTO case law, is the identification of a factual situation and the legal provision that is allegedly violated as a result of its existence. One or more arguments can be raised in support of specific claims. 
originated in an NME, as noted supra). The questionnaires even provided for an example of the product under investigation, namely:

Self-tapping screw, case hardening, not coated, diameter 4,2 millimeters, length 13 millimeters.

So much is clear (paras. 469-470). Pooja Forge, nonetheless, had not provided information on the PCNs requested. The Commission thus based its estimation on product types defined by two factors, strength class and the distinction between standard and special fasteners. The Panel found that the Chinese producers were informed very late in the process about the quality of the information provided by the Indian company, and the ensuing discrepancy with the information they had provided themselves (paras. 461-462). The late notification had as a consequence the impossibility for the Chinese producers to request adjustments. This fact, in and of itself, sufficed for the $A B$ to find that the EU had violated its obligations under Article 6.4 AD (para. 505). A violation of Article 6.4 AD entails ipso facto a violation of Article 6.2 AD since the two provisions are related, one being specific law to the other (para. 506). Due to the Commission's failure to indicate what information was relevant, the Chinese exporters could not exercise their rights under Article 2.4 AD, the provision obliging WTO Members to make fair comparison between NV and EP making due allowances whenever warranted. And here comes the trick: the Panel accepted and the AB confirmed that because of the discrepancy mentioned so far (because of the Commission's attitude), Chinese exporters were not in a position to exercise their rights under this provision (para. 515). But the Panel found no evidence supporting that there were differences affecting price comparability and hence did not find against the EU with respect to China's claim that Article 2.4 AD had been violated. Hence, the AB, upholding the Panel's findings in this respect, found that the EU did not act inconsistently with its obligations under Article 2.4 AD (para. 528, but all paragraphs from para. 519 onwards are relevant to this discussion).

\subsection{Private investigations and confidential information}

Some EU economic operators had provided confidential information without also providing a nonconfidential summary, and, in China's and the Panel's view, the EU, by not insisting that they do so, had violated its obligations under various paragraphs of Article $6 \mathrm{AD}$. The legal regime regarding supply of confidential information is a bit convoluted, and some explanation, albeit brief, is in order.

According to the AD Agreement, information is confidential either by its very nature or because it has been provided on a confidential basis. The Agreement contains an illustrative list of information that is confidential by its very nature. ${ }^{17}$

17 An Illustrative List helps the parties to a contract and/or the judge to avoid a Type II error (a false negative): armed with some specific examples, it will not overlook the application of a law when confronted with cases reflecting similar factual situations. 
A party that provides similar information must show good cause why it should be treated as confidential information, irrespective of whether the information provided is by nature confidential or has been supplied as such. ${ }^{18}$ Additionally, a nonconfidential summary should be provided as well, unless there are exceptional circumstances where its supply is not possible (Article 6.5 AD). The Chinese claim concerns this last point: the EU producers did not provide a nonconfidential summary, and the EU did not insist that they do. As a result, of course, the right of defense of the Chinese companies was negatively affected since they were deprived of information probably crucial to their eventual success before the European IA.

Agrati, an EU producer, for example, had provided a nonconfidential summary of information concerning some injury factors, but not for others. For the latter, the following statement had been included:

The information cannot be summarized without disclosing confidential information which can cause damage to our company. The information has been provided as limited (para. 550).

Fontana Luigi, another EU producer, did not supply a nonconfidential summary with regard to distribution systems and price setting. The reason for doing so was presented in the following terms:

The information is by nature confidential because its disclosure would be of significant competitive advantage to a Competitor (para. 551).

In the AB's view, none of the information provided met the 'exceptional circumstance' standard established in Article 6.5 AD that must be met for the obligation to provide a nonconfidential summary to be waived (para. 553). Consequently, the $\mathrm{AB}$, upholding the Panel, found that the EU had violated its obligations under Article 6.5 AD by accepting the justification of the two companies as valid reasons to waive their obligation to provide a nonconfidential summary.

\section{A critique}

From an economics perspective, the existence of the Antidumping Agreement is difficult to rationalize, given the number of ways in which its language regarding impermissible behaviour by firms competing across borders is inconsistent with permissible profit-maximizing behaviour by firms competing within one country. Thus, in our analysis, we take the Antidumping Agreement as given and focus our critique exclusively on the legal and economic implications of how it is being interpreted and applied in this particular instance.

18 On past case law regarding the 'good cause' requirement, see Mavroidis et al. (2010). 
The first issue that we address is statistical sampling. If antidumping authorities use statistical sampling, how it is used can play a critical role, influencing the outcome of the antidumping investigation. In this particular application, our analysis focuses on three different instances in which the sampling issue arose: (i) in the selection of Chinese exporting firms from which the EU gathered information to make its initial MET decision, (ii) in the use of the Indian firm, Pooja Forge, as an analogue that was used to construct dumping margins for the Chinese exporters who were deemed in an earlier decision to be from a nonmarket economy, and (iii) in the selection of firms in the domestic industry from which the EU gathered information to make its injury determination. ${ }^{19}$

It is worth stepping back and thinking through the likely economic and statistical goals of the statistical-sampling exercise before turning to a critical examination of the EU's applications in this instance. Most importantly, there is no guidance from the Antidumping Agreement or the EU's antidumping provisions to suggest any other goal of the exercise but simply characterizing 'average' behaviour - that is, that which is typically represented by the mean or median of the statistical distribution.

Note that it is not necessary for the Antidumping Agreement or the EU's antidumping provisions to have remained silent about this issue; that is, either could have been written so as to focus the antidumping authority's analysis and attention on something other than 'average' behaviour. For example, one hypothetical possibility would be to explicitly dictate that the antidumping authority's analysis should reflect concern not for the average but for the 'highest' performers-e.g., say, the highest decile or quartile of the distribution-where 'highest' might be based on indicators such as profitability, firm size, a ranking based on the prices of products. Alternatively, or in other settings, provisions might explicitly dictate that the antidumping authority's analysis should reflect Rawlsianlike concern for the 'lowest' performers in the distribution. The main point is that no alternative guidance has been put forward on this issue.

\subsection{Initial sampling of Chinese exporting firms for MET}

The first question is the process by which the EU sampled Chinese exporting firms to gather information to make its initial market-economy test decision. Table 2 summarizes the results of five key phases of the sampling-selection procedure and

19 As one final aside on the noneconomic rationale for antidumping noted above, the mere existence of both so large a number of Chinese exporting firms and domestic (EU) producing firms - numbers so large that it was necessary for the EU to sample rather than survey them all-again highlights the fact that antidumping is not a policy concerned with identifying and dealing with potential predation. The large number of firms suggests few entry barriers, thus making it extremely unlikely that a sufficient number of EU producers would be driven out of business so that Chinese exporting firms would be able to coordinate amongst themselves to then raise prices in a way so as to impose long-run costs on EU consumers due to a lack of market competition. 
Table 2. Results of EU sampling procedure of Chinese exporting firms for the market-economy test

\begin{tabular}{lcc}
\hline \hline Phase of EU investigation & $\begin{array}{c}\text { Remaining number of exporting } \\
\text { firms in the sample at completion } \\
\text { of phase }\end{array}$ & $\begin{array}{c}\text { Share of total China } \\
\text { exports of steel } \\
\text { fasteners to EU }\end{array}$ \\
\hline 1. Initiation of EU investigation & $\begin{array}{c}\mathrm{NA} \\
\text { (though inferred as greater } \\
\text { than 110) } \\
120\end{array}$ & 1.00 \\
2. EU sends out request for exporters to \\
$\begin{array}{l}\text { make themselves known within } 15 \text { days } \\
\text { EU eliminates from sample of } 120 \text { firms } \\
\text { 10 firms that it finds do not produce } \\
\text { fasteners or that are firms that export for } \\
\text { others }\end{array}$
\end{tabular}

Notes: $\mathrm{NA}=$ not available. *Calculated as equal to $0.39 / 0.61$; i.e. $=(9$ 's exports as a share of total exports from PRC)/(9's exports as a share of 110 cooperating firms). * Calculated as equal to $0.54 /(1 / 0.64)$; i.e. $=(5$ 's exports as a share of 110 cooperating firms $) /(1 / 110$ firm's share of exports in total PRC exports).

Source: Authors' tabulation from data provided in EU (2009).

responses that resulted in the sample of Chinese firms whose data the EU ultimately examined to make the MET determination. Step 1 is the initiation of the investigation and thus begins with the universe of Chinese exporting firms which produce $100 \%$ of total fastener exports to the EU, by definition. In Step 2, the EU sent out a general request to Chinese exporters asking to make themselves known; 120 firms came forward as a result. In Step 3, the EU determined that of the 120 firms that revealed themselves as exporting fasteners to the EU, 110 firms were actual exporters, and these firms represented $64 \%$ of total Chinese fastener exports to the EU. In Step 4, the EU decided to select 9 of the 110 firms to provide the detailed data necessary to make the MET determination, and these firms represented 39\% of the universe of Chinese export sales to the EU. In Step 5, the EU threw out the data of four of the nine firms as being unreliable. The remaining five Chinese firms on which the EU based the MET determination combined to represent slightly less than $35 \%$ of the universe of Chinese export sales to the EU.

Is it likely that this sample represented 'average' characteristics of the Chinese exports? In order to address this question, even when focusing on 'average' behaviour, it is important to understand whether the MET should be based on the sampling statistic related to the behaviour of the average 'exporter' (firm) or 
the behaviour of the firm producing the average 'product'. These two are likely to be quite different. As we will see below, the EU's sampling procedure and the selection issues that arise make the second outcome much more likely than the first.

If the goal of the sampling exercise is to capture the behaviour of the average Chinese firm that exports this product to the EU, it is potentially problematic for the EU to make its decision about the market-economy status of more than 110 firms based on information collected from these particular five firms. These five Chinese firms were not drawn from a random sample; that is, they are the result of a multistage process that could result in sample-selection bias stemming from two distinct influences. On the one hand, the Chinese firms that decided to cooperate at Steps 2 and 5 in the investigation may be quite different from the other, nonsampled Chinese firms that did not choose to cooperate. In other words, the Chinese firms' selection of themselves into or out of the sample could be influenced by strategic considerations such as whether the truthful information that they would provide would be harmful or helpful to the outcome that is in their best interest overall. ${ }^{20}$ Furthermore, among the pool of reporting firms, the EU did not randomly sample but instead selected some of the largest exporters. There is extensive economic research literature providing evidence that exporting firms are 'different' - that is, more productive with presumably lower costs for a given level of quality - than other firms (Bernard et al., 2012). It could well follow that larger exporters are then systemically different from smaller exporters, along similar dimensions, and thus making a set of observations that had over-sampled from one segment of the statistical distribution particularly biased. The implication is that the EU approach may be closer to capturing the behaviour of the Chinese firm producing the average product being exported to the EU; it is less likely that this sampling procedure is best able capture the behaviour of the average Chinese firm that is exporting.

To what extent does a potentially biased sample matter for this particular case? Interestingly, if the key determinant regarding whether Chinese firms receive market-economy treatment is not firm-specific, then the difficulty of how to deal with these sample-selection issues could be moot. For example, suppose the technology to make fasteners is relatively common across all Chinese firms and that most of a firm's costs are simply the cost of the steel-wire-rod input. Furthermore, assume that the price of steel-wire rod is not determined by the market (as the EU alleged in the investigation) and finally that access to the subsidized input did not

20 For example, a Chinese exporting firm that is part of a multinational enterprise with production facilities in other countries (that they could reallocate production outside of China) could potentially (and perversely) prefer an outcome in which the EU imposes antidumping duties on all Chinese firms, especially if its main competitors in the EU market are other Chinese firms without production facilities abroad (e.g., Blonigen and Ohno, 1998). Such a firm would presumably make its decision of whether to report at all based on whichever choice led to the greater likelihood of the EU imposing antidumping duties. 
vary across firms. ${ }^{21}$ Because the impact of the subsidized input is common across all Chinese firms that produce and export fasteners, there is no statistical issue of sample selection potentially misinforming the EU's binary choice for whether the entire set of firms operate in a market economy. This is one alternative way to interpret how the EU proceeded.

From an economics perspective, the relevance of the statistical sampling-issue for the MET determination confronting the Panel and the $\mathrm{AB}$ in this case rests on the validity of the EU allegation that the key input of steel-wire rod does not have a price that is determined by the market and that this is enjoyed equally by all Chinese fastener exporting firms. Put differently, the sampling issue is moot if this allegation is correct and if the impact of the nonmarket price for that input is common across all Chinese exporting firms. That is, regardless of whether the EU samples only (any) one firm, collects information from the whole universe of firms, or chooses any option in between, it will always obtain the same result in the MET. Thus, the issue of sampling in this case only becomes relevant if it is incorrect that steel-wire rod is a subsidized input that commonly distorts the costs (and output-pricing decisions) across all Chinese steel-fastener exporting firms.

\section{2 'Sampling' one Indian analogue firm to construct normal values}

Given that the Chinese firms did not pass the MET, a second statistical-sampling issue arises regarding the analogue firms from which the EU constructs the normal value in the dumping-margin calculation. In this instance, the EU chose India as the analogue country and it requested information from two Indian firms, only one of which provided the information. There are at least two sampling issues that arise in this particular case: the choice of country and the sampling of firms.

First, we have insufficient information to assess the choice of India as an analogue country. Nevertheless, it is worth noting from our examination of the publicly available trade data that India had both an extremely small share of the EU import market (relative to China and Taiwan, China-the latter a potential alternative choice for the analogue country), and India had relatively higher unit values than EU imports from both China and Taiwan, China (see again Figure 3a). To the extent that higher unit values in the EU import market correspond to higher costs and higher prices for domestic sales at home, this would make India an attractive candidate for an analogue country.

The second issue results from the fact that the EU chose to request information from only two Indian firms and only one of which, Pooja Forge, provided information that the EU deemed adequate to use to construct the normal value for

21 Note that it does not necessarily follow that if the steel-wire-rod input is subsidized, then there must be common access to the subsidized input across firms. For example, such heterogeneity of access could arise across firms if government subsidy or tax-rebate programs were based on firm characteristics such as size (or access to policymakers), or if their availability differed geographically across regions. 
Table 3. Results of EU sampling procedure of community producers of fasteners for injury test

\begin{tabular}{lcc}
\hline \hline Phase of EU investigation & $\begin{array}{c}\text { Remaining number of firms in } \\
\text { the sample at completion of } \\
\text { phase }\end{array}$ & $\begin{array}{c}\text { Share of total EU steel- } \\
\text { fasteners production }\end{array}$ \\
\hline 1. Initiation of EU investigation & $\begin{array}{c}\text { NA (though 'over } 300 \text { mostly } \\
\text { small and medium-sized } \\
\text { enterprises') }\end{array}$ & 1.00 \\
$\begin{array}{l}\text { 2. EU sends out request for firms to make } \\
\text { themselves known within } 15 \text { days }\end{array}$ & 46 & 0.30 \\
$\begin{array}{l}\text { 3. selects from } 46 \text { cooperating firms } \\
\text { those to survey that had the largest } \\
\text { production volume }\end{array}$ & 7 & $\mathrm{NA}$ \\
$\begin{array}{l}\text { 4. Of the } 7 \text { firms chosen to survey, the EU } \\
\text { decides that } 1 \text { firm refused to cooperate } \\
\text { and eliminates it from sample }\end{array}$ & 6 & 0.27 \\
\hline \hline
\end{tabular}

Note: NA = not available.

Source: Authors' tabulation from data provided in EU (2009).

all of the Chinese firms in the dumping-margin calculation. From a statistical perspective, the result of this process is that the information of only one Indian firm is used to construct the normal value for more than 110 Chinese exporting firms. For statistical reasons alone, it is highly remote that this one Indian firm represents the average Chinese exporting 'firm' (or even the Chinese firm producing the average exported 'product') from the universe of Chinese exporting firms ultimately confronted with the antidumping duty.

\subsection{Sample of EU producers of fasteners for injury test}

A third area of the EU investigation in which the issue of statistical sampling arose is with respect to the injury test for EU producers of the like product. Table 3 illustrates the four-step process by which the EU arrived at the sample of domestic firms by which it collected information so as to determine whether the domestic industry was injured.

Step 1 is the initiation of the investigation and thus begins with the universe of domestic EU firms (producing 100\% of EU total fastener sales, by definition), which the EU reported as 'estimated at over 300 mostly small and medium-sized enterprises but including a few larger companies' (EU, 2009, (112)). In Step 2, the EU sent out a general request that EU producers make themselves known; the result was that 46 firms came forward, which the EU reported as representing $30 \%$ of domestic production. In Step 3, the EU selected seven of the 46 firms (based on volume) to provide the detailed data necessary to make the injury-test determination; these firms represent an unknown share of the universe of EU 
production. In Step 4, the EU throws out the data of one of the seven firms; of the remaining six EU firms on which the injury-test determination is based, the EU reported that they combined to represent $27 \%$ of the universe of EU production volume of fasteners.

A number of the same sampling issues already described above in the context of sampled Chinese exporting firms also arise in the context of EU producers. It is extremely unlikely that these six EU firms represent the average of the universe of EU steel-fasteners producers given that they are the result of a multistage process; the likely result is sample-selection bias stemming from two main influences. Again, given that response to EU requests for information is not compulsory, EU firms may base on strategic considerations their decision regarding whether to select into the sample by positively responding to the request for information. Second, the sample is also not random due to the fact that the EU used the size of the firm (volume of production) as a selection criterion, conditional on the set of firms that voluntarily responded. Indeed, the EU estimated domestic production to be comprised of more than 300 producers of steel fasteners, and most were small- and medium-sized enterprises and not the large-volume firms that were ultimately part of the sample under analysis. While this decision rule ensures that maximal EU production is covered by the injury investigation, it does not follow that the EU is examining whether the average steel-fasteners-producing firm suffered injury. By selecting based on production volume, it is much more likely that the EU is capturing the behaviour of the firm that produces the average 'product' competing with the imported Chinese fasteners and not the average 'firm'.

\subsection{First, a window, then a door: moving away from the obligation to calculate individual dumping margins}

The $\mathrm{AB}$ found that the EU practice to calculate a general (as opposed to individual) rate for Chinese companies because they were considered to belong to an NME was at variance with the EU obligations under the AD Agreement. It did, however, add a passage which allows an IA to deviate from its obligation to calculate individual margins even in cases other than sampling.

The AB Report however, added in paras. 376ff. a passage that offers some additional (to those contemplated by Article 6.10 AD) possibilities to investigating authorities. A small detour to prior case law is necessary: in Korea-Certain Paper, ${ }^{22}$

22 Panel Report, Korea-Anti-Dumping Duties on Imports of Certain Paper from Indonesia, WT/ DS312/R, adopted 28 November 2005. To be sure, the AD Agreement does not explicitly deal with the situation where different offshoots belong to the same economic entity and whether one margin or more (of $\mathrm{AD}$ duties) should be calculated in similar cases. This was a total invention of the AB. In theory, the invention is a good one if the entity adopts the same pricing policy, but only under this very strict condition. In theory also, it could very well be the case that offshoots of the same company (say Chrysler, Germany and Chrysler, UK) adopt divergent pricing policies when exporting to Japan; it would be erroneous in similar cases (and indeed, it would defeat the very purpose of the AD Agreement) to calculate one dumping margin for the two Chrysler companies simply because they belong to the same group even though they 
the Panel had held that an IA can legitimately calculate the same margin for a group of companies that together constitute one economic entity, a 'single entity' being the term it had explicitly used; what exactly this term refers to was not made crystal clear in that Report, but in all likelihood a 'control'-type of criterion seemed appropriate. In EC-Fasteners, the $\mathrm{AB}$ went one step further, and in para. 376 it explained how it understood the term:

These situations may include: (i) the existence of corporate and structural links between the exporters, such as common control, shareholding and management; (ii) the existence of corporate and structural links between the State and the exporters, such as common control, shareholding and management; and (iii) control or material influence by the State in respect of pricing and output.

And later, when discussing the criteria for state control, it noted (para. 381): evidence of State control or instruction of, or material influence on, the behaviour of certain exporters in respect of pricing and output. These criteria could show that in the absence of formal structural links between the State and specific exporters, the State in fact determines and materially influences prices and output.

Now what exactly should we make of all that? The AB, on the one hand, cites Korea-Certain Paper but, on the other, provides a 'wide' understanding of the term 'single entity'. One cannot thus exclude that, upon demonstration of 'influence' by the State (which does not have to be equated to control as the term 'or' used in the quoted paragraph unambiguously suggests) or 'behaviour' by companies (a very loose term and hence, in principle, an easy-to-meet evidentiary standard) IAs could well impose countrywide dumping margins against Chinese companies in the future as well. The $\mathrm{AB}$ closed the door to the possibility for similar calculations for NMEs but opened a huge window through its understanding of 'single entity'. At this stage, the $\mathrm{AB}$ paragraphs quoted above are mere obiter dicta, e.g., they were not decisive for the resolution of the present dispute, and we will thus have to await their first application in a future dispute in order to draw definitive conclusions.

Since these paragraphs were obiter dicta with no operational consequences for the resolution of the dispute, the remaining steps were all downhill for the AB: a violation of Article 6.10 AD leads to a violation of Article 9.2 AD: indeed, how could it be that duties will be collected in appropriate amounts (as Article 9.2 AD requires) if, having determined individual dumping margins, the IA imposes countrywide duties (para. 339)? Arithmetically, a similar endeavor would be correct only in the highly unlikely scenario where all individually calculated dumping margins are identical. This was evidently not the case here.

have adopted divergent pricing policies. The $\mathrm{AB}$ did not adequately explain itself on this score. It seems that thus the original sin was committed already in Korea-Certain Paper. As we will demonstrate in what follows here, in EC-Fasteners, the $\mathrm{AB}$ went down the sinful road a couple of miles. 


\subsection{Is 'Major proportion' a major proportion anymore?}

Recall that, because the EU had inappropriately linked the percentage of the major industry in Article 4.1 AD to that in Article 5.4 AD, the AB found that it had violated its WTO obligations in this respect. This much is clear. But the AB did not stop here, although it could have done so. It went on to provide its own understanding of what constitutes 'major industry', and when doing so, the $\mathrm{AB}$ stated that this term points to a 'relatively high proportion' (para. 419). The AB, however, did not give a number here. Actually, it went as far as to state that a major proportion could be less than $50 \%$ on occasion and as low as $25 \%$ in case of fragmented industries (paras. $415 \mathrm{ff}$.).

All this is reason enough to be worried as to the manner in which this term will be applied in the future: how low a percentage is still high enough to meet the threshold of major proportion? We do not know. And what does the invented term 'fragmented industries' amount to? We do not know. Did the AB try to borrow from antitrust theory where, in case of large numbers of firms serving $2-4 \%$ of the market, a firm with $25 \%$ could be held to be in dominant position? We do not know, but in antitrust analysis barriers to entry in the market will be a key criterion to determine whether dominance exists, and nothing in the $\mathrm{AB}$ Report is reminiscent of this type of analysis.

Unfortunately, the $\mathrm{AB}$ yet again chose to introduce an open-ended term ('fragmented industries') with no statutory underpinnings, the exact parameters of which will be illuminated only in future practice.

\section{Concluding remarks}

The WTO adjudicating bodies are agents with no authority to question the legitimacy of the law itself. They cannot, for example, put into question whether the discretion allowed to IAs to choose between a statistically valid sample (which will provide information regarding the pricing behaviour of the average exporting firm), and a number of exporting firms that can be reasonably investigated (which will more likely instead provide information regarding the pricing behaviour of the firm producing the average product) is well founded. As a result, our critique of the Report cannot focus on shortcomings of the law itself.

Like other Reports in the area of contingent protection, this Report evidences the rather 'liberal' attitude of the $A B$ when dealing with these issues. For example, the $\mathrm{AB}$ could have stopped when finding that the EU cannot calculate an 'all others rate' to products originating in an NME. There was little need to discuss the possibility to do so if there is a particular relationship between the state and its 'national' companies. And yet it did, as the Panel had done before in Korea-Certain Paper. By the same token, it could have stopped its analysis when finding that the threshold established in Article 5.4 AD cannot be used 'lock, stock, and barrel' in the context of analysis under Article 4.1 AD. And yet it did not and moved on to 
provide its understanding of how this term should be understood using 'plastic' terms that we have no idea how they will be molded in the future. In the past, the $\mathrm{AB}$ has evidenced a similar attitude when dealing with challenges in the context of sunset reviews.

Surprisingly, it is the $\mathrm{AB}$, a body often accused for being overtly textualist when interpreting WTO law, that has recourse to similar interpretative attitudes. Furthermore, this type of judicial activism has thus far managed to escape the attention of critics. Nevertheless, its consequences could be spectacular: the AB in future case law could hold that Chinese, Vietnamese, etc. companies have particular links with the state, and, hence, there is no obligation for an IA to calculate individual margins. Instead, IAs could stop at determining national rates; the risk for abuses here should not be underestimated. In this respect, the AB may be overconfident if it believes that it can 'tame' exuberant IAs in the future; for one, the $\mathrm{AB}$ is no trier of facts, and the question of links between companies and the state is an eminently factual issue. This point alone should give pause to the $A B$ in this area in future practice.

\section{References}

Bernard, A. B., J. B. Jensen, S. J. Redding, and P. K. Schott (2012), 'The Empirics of Firm Heterogeneity and International Trade', Annual Review of Economics, 4: 283-313.

Blonigen, B. A. (2002), 'Tariff-Jumping Antidumping Duties', Journal of International Economics, 57(1): 31-49.

Blonigen, B. A. and Y. Ohno (1998), 'Endogenous Protection, Foreign Direct Investment and Protectionbuilding Trade', Journal of International Economics, 46(2): 205-227.

Bown, C. P. (2012), Temporary Trade Barriers Database, World Bank, available at http://econ.worldbank .org/ttbd/ (last visited 19 October 2012).

Czako, J., J. Human, and J. Miranda (2003), A Handbook on Anti-Dumping Investigations, Cambridge: Cambridge University Press.

European Union (EU) (2009), 'Council Regulation (EC) No. 91/2009: Imposing a Definitive Anti-Dumping Duty on Imports of Certain Iron or Steel Fasteners Originating in the People's Republic of China', Official Journal of the European Union, L 29/1, 31 January.

European Union (EU) (2010), 'Commission Regulation (EU) No. 966/2010', Official Journal of the European Union, L 282/29, 27 October.

European Union (EU) (2011), 'Regulations: Council Implementing Regulation (EU) No. 723/2011', Official Journal of the European Union, 18 July.

Horn, H., L. Johannesson, and P. C. Mavroidis (2011), 'The WTO Dispute Settlement System 1995-2010: Some Descriptive Statistics', Journal of World Trade, 45(6): 1107-1138.

KAMAX (2012a), 'Company', available at http://www.kamax.com/en/company/, last visited 19 October 2012.

KAMAX (2012b), 'Locations', available at http://www.kamax.com/en/company/locations/, last visited 19 October 2012.

Khandelwal, A. K. (2010), 'The Long and Short (of) Quality Ladders', Review of Economic Studies, 77(4): 1450-1476.

Mavroidis, P. C., P. A. Messerlin, and J. M. Wauters (2010), The Law and Economics of Contingent Protection in the WTO, Cheltenham, UK: Edward Elgar.

Mavroidis, P. C. and A. Sapir (2008), 'Mexico: Antidumping Measures on Rice: Don't Ask Me no Questions and I won't Tell No Lies', World Trade Review, 7(1): 305-323. 
Palmeter, N. D. (1995), 'United States Implementation of the Uruguay Round Antidumping Code', Journal of World Trade, 29(3): 39-82.

Schott, P. K. (2008), 'The Relative Sophistication of Chinese Exports', Economic Policy, 53(1): 5-49.

Stewart, T. P., A. S. Dwyer, D. A. Gantz, and T. J. Prusa (2009), 'Antidumping: Overview of the Agreement', in K. W. Bagwell, G. A. Bermann, and P. C. Mavroidis (eds.), Law and Economics of Contingent Protection in International Trade, Cambridge: Cambridge University Press, pp. 197-263.

Zang, M. Q. (2011), 'EC-Fasteners: Opening Pandora's Box of Non-Market Economy Treatment', Journal of International Economic Law, 14(4): 869-892. 